\title{
ATENOLOL EPOXIDE REACTION DATA ANALYSIS IN BATCH REACTOR
}

\author{
Pooja.K.Jadhav ${ }^{1}$, Rashmi.S.Deshpande ${ }^{2}$ \\ ${ }^{I}$ M.E student, Chemical Department, Sinhgad College of Engineering, Maharashtra, India \\ ${ }^{2}$ Asst. Professor, Chemical Department, Sinhgad College of Engineering, Maharashtra, India
}

\begin{abstract}
In this paper Integral method of analysis of data for Batch reactor is used to find the rate and order of reaction of Atenolol epoxide. The integral method is useful for fitting simple chemical reactions. This method puts a particular rate equation to test by integrating and comparing the predicted $C$ versus $t$ curve with experimental $C$ versus $t$ data. If the fit is unsatisfactory, another rate equation is tested. The key raw materials required to produce Atenolol epoxide are Parahydroxyphenylacetamide (PHPA) and Epichlorohydrine (EPH). Firstly, the order and rate with respect to reactant i.e. PHPA is tested and then overall order and rate of equation is evaluated with Integral method of analysis of data. The integrated rate law depends on the kinetics. Since the reaction is being carried out in a batch reactor, the volume of reactor is assumed constant throughout the reaction. The theoretical and actual rates of reaction are then compared for various concentrations of reactant.
\end{abstract}

Keywords: Batch reactor, Irreversible bimolecular-type second order reaction, Theoretical rate constant, Integral method of analysis, Experimental rate.

\section{ATENOLOL EPOXIDE}

Atenolol Epoxide is produced by condensing PHPA and $\mathrm{EPH}$, the reaction is being carried out in a one litre, 3 mouthed round bottom flask at isothermal conditions and with constant stirring [1].

\section{$\mathrm{PHPA}+\mathrm{EPH} \quad \longrightarrow \quad$ ATENOLOL EPOXIDE}

Concentrations versus time data are obtained for reactants and integrated method for finding the rate law are checked for first and second order reactions.

\section{COMPARISON BETWEEN THEORETICAL}

\section{AND ACTUAL RATE, FOR CHANGE IN CONCENTRATION DATA}

Various batches with change in concentration of key reactant PHPA were carried out and their order and rate of reaction was calculated. Further the theoretical rate was calculated and experimental rate was found by integral method of analysis data.[2]

\section{FOR 60 GM PHPA BATCH}

\subsection{Overall Order}

Overall order is sum of order with respect to each reactant, i.e. sum of orders of both the reactants[2]. Both reactants are first order therefore, overall order is second order, which can be proved with integral method of analysis.

Plot a graph of $\operatorname{lnC}_{\mathrm{B}} / \mathrm{C}_{\mathrm{A}}$ vs time and $\ln \mathrm{C}_{\mathrm{B}} \mathrm{C}_{\mathrm{A} 0} / \mathrm{C}_{\mathrm{A}} \mathrm{C}_{\mathrm{B} 0}$ vs time.[2] - $* * *$

Table -1: $\ln C_{B} / C_{A}$ data

\begin{tabular}{|l|l|l|l|}
\hline Time(hours) & $\begin{array}{l}\mathrm{C}_{\mathrm{A}} \\
\text { moles/liter in }\end{array}$ & $\begin{array}{l}\mathrm{C}_{\mathrm{B}} \\
\text { moles/liter }\end{array}$ & $\ln \mathrm{C}_{\mathrm{B}} / \mathrm{C}_{\mathrm{A}}$ \\
\hline 0 & 0.6622 & 1.1166 & 0.5224 \\
\hline 2 & 0.5764 & 1.03098 & 0.5814 \\
\hline 4 & 0.4543 & 0.9088 & 0.6933 \\
\hline 6 & 0.368 & 0.828 & 0.8109 \\
\hline 8 & 0.191 & 0.6455 & 1.2177 \\
\hline
\end{tabular}

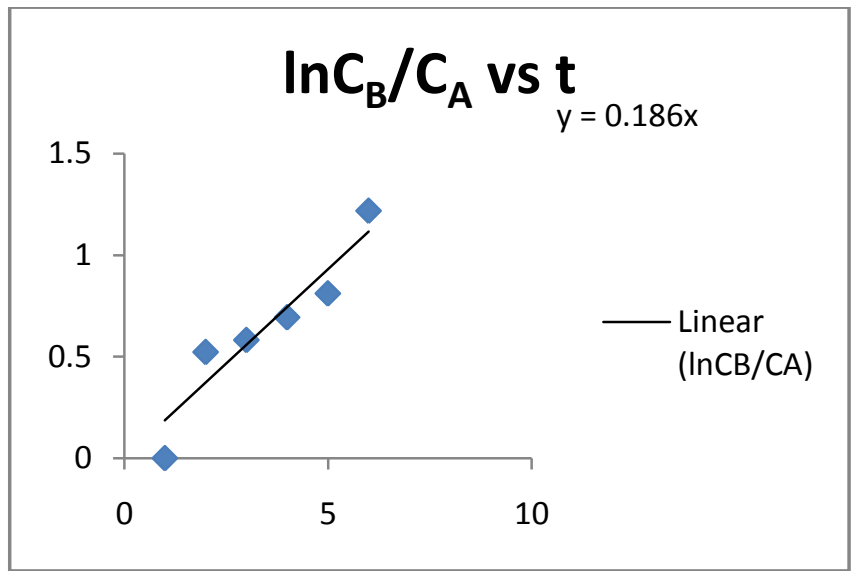

Chart -1: $\ln C_{B} / C_{A}$ vs t

From graph it can be seen that, slope $=\left(\mathrm{C}_{\mathrm{B} 0}-\mathrm{C}_{\mathrm{A} 0}\right) \mathrm{k}=0.186$, value of $\mathrm{k}$ can be calculated, $\mathrm{k}=0.409 \mathrm{~L} / \mathrm{molhr}$.[3]

$$
-\mathrm{r}_{\mathrm{A}}=0.409 \mathrm{C}_{\mathrm{A}} \mathrm{C}_{\mathrm{B}}
$$

Therefore, straight line in graph proves that the concentration vs time data fits to second order kinetics. 


\subsection{Theoretical rate}

$$
\begin{gathered}
-r_{A}=-\frac{d C_{A}}{d t}=-\frac{(0.191-0.6622)}{(8-0)}=0.0589 \mathrm{~mol} / \mathrm{Lhr} \\
0.0589=k_{t h} C_{A} C_{B}
\end{gathered}
$$

Where $k_{t h}=$ theoretical rate constant

$$
\begin{gathered}
0.0589=k_{t h}(0.4266)(0.8858) \\
k_{t h}=0.156 \mathrm{~L} / \mathrm{molhr}
\end{gathered}
$$

Calculating theoretical rates at various time during reaction.

At $0 \mathrm{hr}$

$$
-r_{1}=0.156(0.662)(1.1166)=0.1153 \mathrm{~mol} / \mathrm{Lhr}
$$

At $2 \mathrm{hr}$

$$
-r_{2}=0.156(0.576)(1.0309)=0.09269 \mathrm{~mol} / \mathrm{Lhr}
$$

At $4 \mathrm{hr}$

$$
-r_{3}=0.156(0.4543)(0.9088)=0.0644 \mathrm{~mol} / \mathrm{Lhr}
$$

At $6 \mathrm{hr}$

$$
-r_{4}=0.156(0.368)(0.828)=0.0475 \mathrm{~mol} / \mathrm{Lhr}
$$

At $8 \mathrm{hr}$

$$
-r_{5}=0.156(0.191)(0.6455)=0.0192 \mathrm{~mol} / \mathrm{Lhr}
$$

\subsection{Actual Rate or Experimental Rate}

From graph

$$
\begin{aligned}
& -r_{A}=0.409 C_{A} C_{B} \\
& k_{e x}=0.409 \frac{L}{\text { molhr }}
\end{aligned}
$$

Where $\mathrm{k}_{\mathrm{ex}}=$ experimental rate constant

Calculating experimental rates at various time during reaction[3]

At $0 \mathrm{hr}$

$$
r_{1}=0.409(0.662)(1.1166)=0.303 \mathrm{~mol} / \mathrm{Lhr}
$$

At $2 \mathrm{hr}$

$$
-r_{2}=0.409(0.576)(1.0309)=0.2430 \mathrm{~mol} / \mathrm{Lhr}
$$

At $4 \mathrm{hr}$

$$
-r_{3}=0.409(0.4543)(0.9088)=0.1688 \mathrm{~mol} / \mathrm{Lhr}
$$

At $6 \mathrm{hr}$

$$
-r_{4}=0.409(0.368)(0.828)=0.1246 \mathrm{~mol} / \mathrm{Lhr}
$$

At $8 \mathrm{hr}$

$$
-r_{5}=0.409(0.191)(0.6455)=0.05042 \mathrm{~mol} / \mathrm{Lhr}
$$

Table-2: Comparison between theoretical and experimental rate

\begin{tabular}{|l|l|l|}
\hline Time $(\mathrm{hr})$ & $\begin{array}{l}\text { Theoretical rate } \\
(\mathrm{mol} / \mathrm{Lhr})\end{array}$ & $\begin{array}{l}\text { Experimental rate } \\
(\mathrm{mol} / \mathrm{Lhr})\end{array}$ \\
\hline 0 & 0.1153 & 0.303 \\
\hline 2 & 0.0926 & 0.2430 \\
\hline 4 & 0.0644 & 0.1688 \\
\hline 6 & 0.0475 & 0.1246 \\
\hline 8 & 0.0192 & 0.05042 \\
\hline
\end{tabular}

\section{FOR 50 GM PHPA BATCH}

\subsection{Overall Order}

Overall order is sum of order with respect to each reactant, i.e. sum of orders of both the reactants[4]. Both reactants are first order therefore; overall order is second order, which can be proved with integral method of analysis.

Plot a graph of $\ln C_{B} / C_{A}$ vs time and $\ln C_{B} C_{A 0} / C_{A} C_{B 0}$ vs time.

Table -3: $\ln \mathrm{C}_{\mathrm{B}} / \mathrm{C}_{\mathrm{A}}$ and $\ln \mathrm{C}_{\mathrm{B}} \mathrm{C}_{\mathrm{A} 0} / \mathrm{C}_{\mathrm{A}} \mathrm{C}_{\mathrm{B} 0}$ data

\begin{tabular}{|l|l|l|l|}
\hline Time(hours) & $\begin{array}{l}\mathrm{C}_{\mathrm{A}} \\
\text { moles/liter }\end{array}$ & $\begin{array}{l}\mathrm{C}_{\mathrm{B}} \\
\text { moles/liter }\end{array}$ & $\ln \mathrm{C}_{\mathrm{B}} / \mathrm{C}_{\mathrm{A}}$ \\
\hline 0 & 0.5518 & 1.11660 & 0.70472 \\
\hline 2 & 0.3297 & 0.89450 & 0.99808 \\
\hline 4 & 0.2466 & 0.81142 & 0.19101 \\
\hline 6 & 0.0682 & 0.63305 & 2.22722 \\
\hline 8 & 0.00424 & 0.56903 & 4.89937 \\
\hline
\end{tabular}

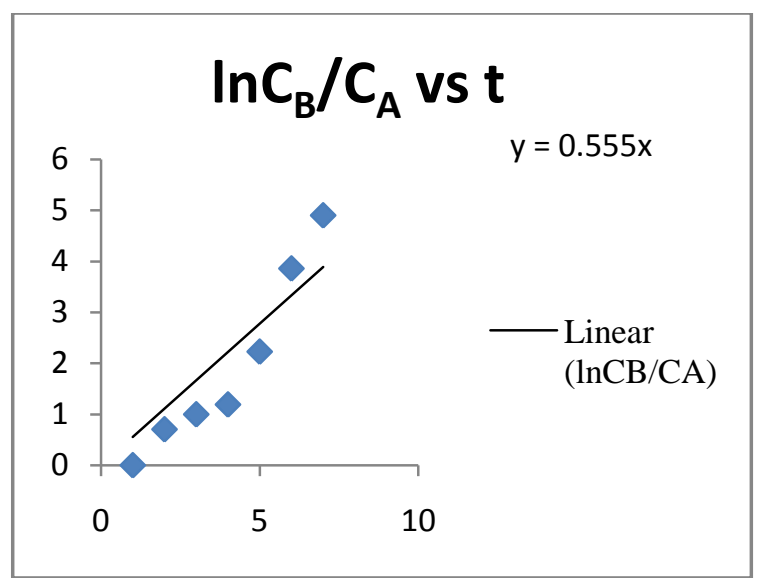

Chart -2: $\ln C_{B} / C_{A}$ vs t

From graph it can be seen that slope $=\left(\mathrm{C}_{\mathrm{B} 0}-\mathrm{C}_{\mathrm{A} 0}\right) \mathrm{k}=0.555$, value of $\mathrm{k}$ can be calculated, $\mathrm{k}=0.982 \mathrm{~L} / \mathrm{molhr}$.[4]

$$
-r_{\mathrm{A}}=0.982 \mathrm{C}_{\mathrm{A}} \mathrm{C}_{\mathrm{B}}
$$

Therefore, straight line in graph proves that the concentration vs time data fits to second order kinetics.

\subsection{Theoretical Rate}

$$
\begin{aligned}
-r_{A}=-\frac{d C_{A}}{d t}=- & \frac{(0.00424-0.551)}{(8-0)} \\
& =0.06844 \mathrm{~mol} / \mathrm{Lhr}
\end{aligned}
$$




$$
0.06844=k_{t h} C_{A} C_{B}
$$

Where $k_{t h}=$ theoretical rate constant

$$
\begin{gathered}
0.06844=k_{t h}(0.278)(0.8428) \\
k_{t h}=0.2921 \mathrm{~L} / \mathrm{molhr}
\end{gathered}
$$

Calculating theoretical rates at various time during reaction.

\subsection{Actual Rate or Experimental Rate}

From graph

$$
\begin{aligned}
& -r_{A}=0.982 C_{A} C_{B} \\
& k_{\text {ex }}=0.982 \frac{L}{\text { molhr }}
\end{aligned}
$$

Where $\mathrm{k}_{\mathrm{ex}}=$ experimental rate constant

Calculating experimental rates at various time during reaction.[5]

Table-4: Comparison between theoretical and experimental rates

\begin{tabular}{|l|l|ll|}
\hline Time (hr) & $\begin{array}{l}\text { Theoretical rate } \\
(\mathrm{mol} / \mathrm{Lhr})\end{array}$ & $\begin{array}{l}\text { Experimental rate } \\
(\mathrm{mol} / \mathrm{Lhr})\end{array}$ \\
\hline 0 & 0.1799 & 0.605 \\
\hline 2 & 0.0861 & 0.2896 \\
\hline 4 & 0.0584 & 0.1964 \\
\hline 6 & 0.0126 & 0.0424 \\
\hline 8 & 0.0007 & 0.0023 \\
\hline
\end{tabular}

\section{FOR 40 GM PHPA BATCH}

\subsection{Overall Order}

Overall order is sum of order with respect to each reactant, i.e. sum of orders of both the reactants[6]. Both reactants are first order therefore; overall order is second order, which can be proved with integral method of analysis.

Plot a graph of $\ln _{B} / C_{A}$ vs time and $\ln C_{B} C_{A 0} / C_{A} C_{B 0}$ vs time.

Table-5: $\ln \mathrm{C}_{\mathrm{B}} / \mathrm{C}_{\mathrm{A}}$ and $\ln \mathrm{C}_{\mathrm{B}} \mathrm{C}_{\mathrm{A} 0} / \mathrm{C}_{\mathrm{A}} \mathrm{C}_{\mathrm{B} 0}$ data

\begin{tabular}{|l|l|l|l|l|}
\hline $\begin{array}{l}\text { Time(hou } \\
\text { rs) }\end{array}$ & $\begin{array}{l}\mathrm{C}_{\mathrm{A}} \text { in } \\
\text { moles/lit } \\
\text { er }\end{array}$ & $\begin{array}{l}\mathrm{C}_{\mathrm{B}} \text { in } \\
\text { moles/lit } \\
\text { er }\end{array}$ & $\ln \mathrm{C}_{\mathrm{B}} / \mathrm{C}_{\mathrm{A}}$ & $\begin{array}{l}\ln \left(\mathrm{C}_{\mathrm{B}} \mathrm{C}_{\mathrm{A} 0}\right. \\
\left./ \mathrm{C}_{\mathrm{A}} \mathrm{C}_{\mathrm{B} 0}\right)\end{array}$ \\
\hline 0 & 0.4420 & 1.1166 & 0.926734 & 0 \\
\hline 2 & 0.2268 & 0.9019 & 1.380435 & 0.453701 \\
\hline 4 & 0.0927 & 0.7689 & 2.115592 & 1.188859 \\
\hline 6 & 0.0871 & 0.763 & 2.170201 & 1.243467 \\
\hline 8 & 0.0130 & 0.688 & 3.968839 & 3.042106 \\
\hline
\end{tabular}

\section{$\ln C_{B} / C_{A}$ vs $t$}

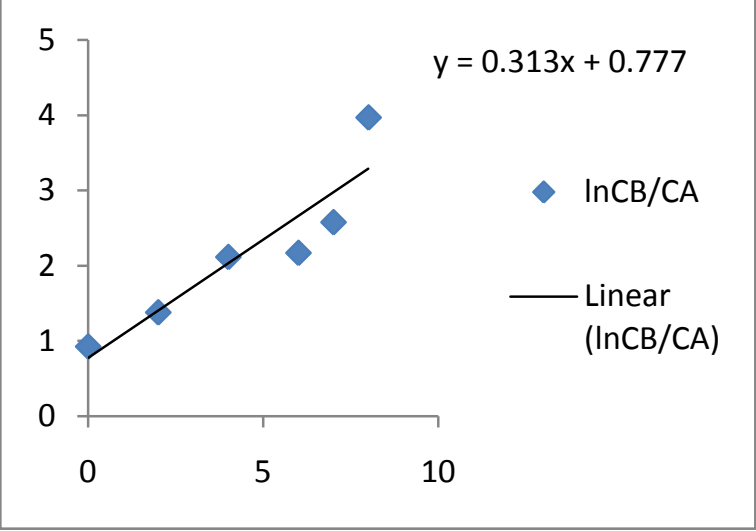

Chart -3: $\ln C_{\mathrm{B}} / \mathrm{C}_{\mathrm{A}}$ vs t

From both graphs we can see slope $=\left(\mathrm{C}_{\mathrm{B} 0}-\mathrm{C}_{\mathrm{A} 0}\right) \mathrm{k}=0.313$, value of $\mathrm{k}$ can be calculated, $\mathrm{k}=0.464 \mathrm{~L} / \mathrm{molhr}$.[7]

$$
-r_{A}=0.464 C_{A} C_{B}
$$

Therefore, straight line in both graphs proves that the concentration vs time data fits to second order kinetics.

\subsection{Theoretical Rate}

$$
\begin{gathered}
-r_{A}=-\frac{d C_{A}}{d t}=-\frac{(0.0130-0.4420)}{(8-0)}=0.0536 \mathrm{~mol} / \mathrm{Lhr} \\
0.0536=k_{t h} C_{A} C_{B}
\end{gathered}
$$

Where $k_{t h}=$ theoretical rate constant

$$
\begin{gathered}
0.0536=k_{t h}(0.2275)(0.9023) \\
k_{t h}=0.2612 \mathrm{~L} / \mathrm{molhr}
\end{gathered}
$$

Calculating theoretical rates at various time during reaction.

\subsection{Actual Rate or Experimental Rate}

From graph

$$
\begin{aligned}
& -r_{A}=0.464 C_{A} C_{B} \\
& k_{e x}=0.464 \frac{L}{\text { molhr }}
\end{aligned}
$$

Where $\mathrm{k}_{\mathrm{ex}}=$ experimental rate constant

Calculating experimental rates at various time during reaction.[8]

Table-6: Comparison between theoretical and experimental rates

\begin{tabular}{|l|l|l|}
\hline Time $(\mathrm{hr})$ & $\begin{array}{l}\text { Theoretical rate } \\
(\mathrm{mol} / \mathrm{Lhr})\end{array}$ & $\begin{array}{l}\text { Experimental rate } \\
(\mathrm{mol} / \mathrm{Lhr})\end{array}$ \\
\hline 0 & 0.1289 & 0.2291 \\
\hline 2 & 0.0534 & 0.0949 \\
\hline 4 & 0.0186 & 0.0331 \\
\hline
\end{tabular}




\begin{tabular}{|l|l|l|}
\hline 6 & 0.0173 & 0.0308 \\
\hline 8 & 0.0023 & 0.0042 \\
\hline
\end{tabular}

\section{RESULTS AND CONCLUSIONS}

Overall order of reaction is second order, proved using integral method of analysis. This method is also used to find the overall rate equation and the value of rate constant. The reaction of Atenolol epoxide is a homogeneous reaction with no catalyst used. The concentrations versus time data are used to find the order of reaction.Comparison of theoretical and experimental rates is done. Concentration of reactant decreases as reaction proceeds with time. Effect of concentration of reactant is studied by varying the concentrations of PHPA. The batch with $60 \mathrm{gm}$ PHPA used shows that the reactant remains unreacted as compared to 50 gm batch.

\section{ABBREVIATIONS AND NOMENCLATURE}

PHPA- Parahydroxyphenylacetamide EPH- Epichlorohydrine

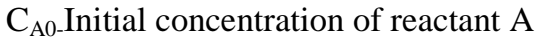

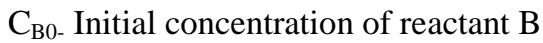

$\mathrm{C}_{\mathrm{A}}$ - Concentration of $\mathrm{A}$

$\mathrm{C}_{\mathrm{B}-}$ Concentration of $\mathrm{B}$

$\mathrm{X}_{\mathrm{A}}$ - Fractional Conversion of $\mathrm{A}$

$r_{i}$ - Reaction rate of component $i$

\section{ACKNOWLEDGEMENTS}

At this moment of accomplishment, I pay thanks to my guide, Prof. Rashmi. S. Deshpande, Chemical Engineering Department, Sinhgad college of Engineering, Vadgaon (BK) ,Pune 41. This work would not have been possible without her valuable guidance, support and encouragement. Under her guidance I successfully overcame many difficulties and learned a lot. Her energy and clear way of thinking were the driving force for me at all stages.

\section{REFERENCES}

[1] Rafik Karaman, Alaa Qtait, Khulod Khayyat Dajani, and Saleh Abu Lafi,"Design, Synthesis, and In Vitro Kinetics Study of Atenolol Prodrugs for the Use in Aqueous Formulations", The Scientific World Journal Vol 2014, Article ID 248651, pp 13, December 2013.

[2] Maricel Torrent, Liqun Deng, Miquel Duran, Miquel Sola, and Tom Ziegler, "Mechanisms for the formation of epoxide and chlorine-containing products in the oxidation of ethylene by chromyl chloride", Canadian Journal of Chemistry,77, pp 1476-1491, December 1999.

[3] Rachaneebhorn Inkum,Aphiwat Teerawutgulrag, Pakawan Puangsombat and Nuansri Rakariyatham, "An alternative synthesis of (+)-propranolol and (+)atenolol", Maejo International Journal of Science and Technology, ISSN 1905-7873, vol. 03, pp 372-378, 15 October 2012.

[4] Rafael.N.Pereira,Bruno.Valente,Ariane.Cruz,Talize Foppa and Marcos A Silva, "Thrmoanalytical study of Atenolol and Commercial tablets", Latin American Journal of Pharmacy, Vol 26(3), pp 382386, 2007.

[5] Nandini .Pai and Swapnali Patil, "Synthesis of Atenolol Impurities", Journal of Chemical and Pharmaceutical Research, Vol 4(1), pp 375-382, 2012.

[6] Rashmi Agarwal and Fadnis. Anand, "Kinetic and Mechanistic study of oxidation of Atenolol by Cerium (IV) in Sulphuric acid Medium”, International Research Journal of Pharmacy, ISSN 2230-8407, pp268-270, vol 02, March 2012.

[7] Rahul Kawthekar, Wen Tao Bi,and Geon Joong Kim, "Asymmetriac ring opening of Epoxides Catalysed by Novel Heterobimettalic Schiff- Bases containing Transition Metal Salts", Korean Chemical Socirty, Vol 29, pp 313-318, August 2007.

[8] G Hiremath, R Kulkarni and S.T.Nandibewoor, "Kinetics of Oxidative Degradation and Deamination of Atenolol by Aqueous Alkaline Permanganate", Indian Journal of Chemistry, Vol 44, pp 245-250, February 2005. 